EPA-600/2-76-126

May 1976

$$
\begin{aligned}
& \text { NBSIR75-970(R) } \\
& P B 253-252
\end{aligned}
$$

Environmental Protection Technology Series

$$
\begin{aligned}
& \text { Sueverso of cove for other } \\
& \text { non-NBS media }
\end{aligned}
$$

\title{
DEVELOPMENT OF THIN CALIBRATION STANDARDS FOR X-RAY FLUORESCENCE ANALYSIS
}

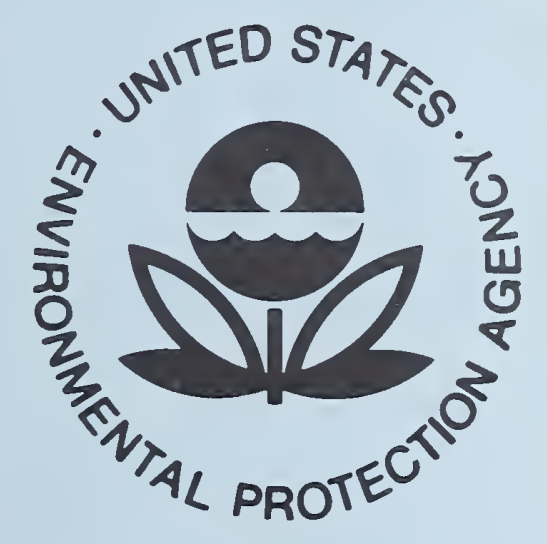

Environmental Sciences Research Laboratory Office of Research and Development U.S. Environmental Protection Agency Research Triangle Park, North Carolina 27711 


\section{RESEARCH REPORTING SERIES}

Research reports of the Office of Research and Development, U.S. Environmental Protection Agency, have been grouped into five series. These five broad categories were established to facilitate further development and application of environmental technology. Elimination of traditional grouping was consciously planned to foster technology transfer and a maximum interface in related fields. The five series are:

\section{Environmental Health Effects Research \\ 2. Environmental Protection Technology \\ 3. Ecological Research \\ 4. Environmental Monitoring \\ 5. Socioeconomic Environmental Studies}

This report has been assigned to the ENVIRONMENTAL PROTECTION TECHNOLOGY series. This series describes research performed to develop and demonstrate instrumentation, equipment, and methodology to repair or prevent environmental degradation from point and non-point sources of pollution. This work provides the new or improved technology required for the control and treatment of pollution sources to meet environmental quality standards.

Pelia, P. A., Kuchner, Z. C., Cassatt, H. A., Devalopment of a partiulate reference sample on membrane filters fon the standardization o= $x$-ray fluorescence spectrometers, (Proc. 24th

Annual Conf. on Applicezions of X-Ray Analysis, Denver, Co, Aug. 6-8, 1975), Chapter in Advances in $\mathrm{X}$-Ray fnezjis, $\mathrm{R}$. U. Gould, C. S. Barrett, J. B. Nesirr and C. O. Ruua, Eds., 19, 463-472 (Kendell/Funt Publ. Co., Dubuque, Iowa, 1975).

Pella, P. A., Kuehner, E. C., Cassatt, W. A., Development of thin calibration standards for $x$-ray fluorescence analysis, Envircnmental Protection Technology Series, EPA-600/2-76-126, 11 pages (available as PE253252 from the National Technical Information Service, Springfield, Va., 22151, May 1976).

\section{0}

NBSIR 75-970(R) 


\section{DEVELOPNENT OF THIIV CALIBRATION STANDARDS \\ FOR X-RAY FUUORESCENCE AITALYSIS}

\section{by}

P. A. Pella, E. C. Kuehner, and W. A. Cassatt National Bureau of Standards Washington, DC 20234

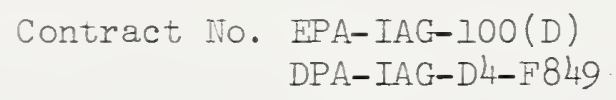

\section{Project Officer}

T. G. Dzubay

Atmospheric Chemistry and Physics Division Environmental Sciences Research Laboratory Research Triangle Park, NC 27711

U.S. EIVIRONMENTAL PROTECTION AGENCY OFFIC 2 OF RESEARCH AND DEVELOPMENT ENVIROINEINTAL SCIENCES RESEARCH LABORATORY RESEARCH TRIANGLE PARK, INC 27711 


\section{DISCLAIMER}

This report has been reviewed by the Environmental Science Research Laboratory, U.S. Environmental Protection Agency, and approved for publication. Approval does not signify that the contents necessarily reflect the views and policies of the U.S. Environmental Protection Agency, nor endorsement or recommendation for use. 


\section{IINTRODUCTION}

Witnir tre past several years, an increasing number of $x$-ray analyses of enviromental and biological samples have been reported in which the National Bureau of Standards Standard Reference Material (SRM) 1571 orchard leaves was used as a trace element calibration standard [I-3]. This botanical SRM is well suited to such applications because it contains a number of trace elements such as $\mathrm{S}, \mathrm{Cl}, \mathrm{K}, \mathrm{Ca}, \mathrm{Cr}, \mathrm{Mn}, \mathrm{Fe}, \mathrm{Co}, \mathrm{Ni}, \mathrm{Cu}$, $\mathrm{In}$, As and $\mathrm{Pb}$ which are important in the analysis of environmental samples. In the analysis of ambient air particulates, the sample analyzed is often in the form of thin deposits on either membrane or Whatman type filters. Therefore, it is desirable to have a calibration sample in the same form. The preparation of orchard leaf deposits on membrane filters to be used for this purpose is described in this report.

The INBS SRI as certified requires that at least $250 \mathrm{mg}$ samples be taken to insure that the trace element distribution is representative of the bulk material. To permit smaller samples to be used and to minimize the attenuation of $x$-rays in the individual particles, the material was reground. A number of different coatings were investigated to provide good sample protection, and at the same time obtain low attenuation of the $x$-rays from elements such as phosphorus and sulfur. Different coating materials that were investigated consisted of polyisobutylene, heat-sealed overlays of polypropylene and Parafilm, and vapor-deposited Parylene films.

\section{EXPERIMENTAL}

Sample deposits were prepared by filtration of a suspension of the reground material in cyclohexane. Attempts were made to prepare deposits from an aerosol suspension, but were not successful.

\section{A. Grinding of the Orchard Leaves SRM 1571}

A high velocity air impact grinder was used to reduce the particle sizes. The impactor produces two size fractions having relatively broad size distributions. The "fines" fraction was collected after each pass through the grinder and was reground four times. The particle size distribution of the collected material was characterized by automated image analysis. Data wert taken by examining nine regions of four different sample preparations. These samples were prepared by dispersing a few milligrams of material in cyclohexane with ultrasonic stirring. About three drops of this suspension were placed on a microscope slide, covered with a cover zlass and allowed to dry.

\section{B. Preparation of Deposits on Membrane Filters}

From 2 to 15 mg of äried reground orchard leaves were weighed and transferred to a $50 \mathrm{ml}$ beaker containing about $40 \mathrm{ml}$ of spectrograde cyclohexane. The beaker containing the orchard leaves was placed in an 
ultrasonic bath for about one minute to disperse the particles. The suspension was transferred to a vacuum filtering unit and the sides of the beaker were washed down with cyclohexane. The material was filtered rapidly through a $37 \mathrm{~mm}$ preweighed membrane filter ( $0.8 \mu \mathrm{m}$ pore size). The glass filtering funnel was constructed so that deposits on the $37 \mathrm{~mm}$ membrane filters were $29 \mathrm{~mm}$ in diameter. The net weight of the air-dried deposit was used to calculate the areal density of the deposit in $\mathrm{mg} / \mathrm{cm}^{2}$. All weighings were performed in a room in which the relative humidity was maintained at $50 \pm 4$ percent.

\section{Preparation of Parylene-Coated Samples}

The samples were coated at the Union Carbide Corporation with a thin film of Parylene $\mathrm{N}$ - a polymeric material developed by Union Carbide Corporation (U.S. Patent No. 3342754). The procedure consists of first vaporizing the di-para-xylylene dimer by heating it at $175^{\circ} \mathrm{C}$ at $760 \mathrm{~mm} \mathrm{Hg}\left(1.01 \times 10^{5} \mathrm{~N} / \mathrm{m}^{2}\right)$. This vaporized material passes through a deposition chamber maintained at room temperature, and $0.1 \mathrm{~mm} \mathrm{Hg}\left(13.3 \mathrm{~N} / \mathrm{m}^{2}\right)$ which contains the samples to be coated. The samples are rotated in the chamber to insure a uniform coating of Parylene. The exit of the deposition chamber is connected to a cold trap $\left(-70^{\circ} \mathrm{C}\right)$ and pumped with a mechanical pump to a pressure of $0.001 \mathrm{~mm} \mathrm{Hg}\left(0.133 \mathrm{~N} / \mathrm{m}^{2}\right)$. The film thickness is monitored in the deposition chamber using a piezoelectric frequency sensor. More accurate thickness measurements were made at Union Carbide after removal of the samples using a UV spectrophotometer. The thickness is calculated from a calibration curve by comparing the absorbance of the film with that of a film of known thickness measured interferometrically.

\section{Preparation of Thin-Film Overlays of Parafilm and Polypropylene}

A sheet of Parafilm (American Can Co.) was stretched by hand as thinly as possible without causing the sheet to tear, and was placed directly on the sample which was held by suction to a filtering funnel. A polypropylene sheet $(0.08 \mathrm{~mm}$ thick) was next placed on top of the Parafilm and was heatsealed to the sample using a hot air gun.

\section{E. Mounting the Parylene-Coated Filter Deposit}

Filter holders for mounting the deposits were supplied by EPA, and are described in an EPA report [4]. These holders, designed to accommodate $37 \mathrm{~mm}$ diameter membrane filters, were modified by increasing the platform diameter by $2 \mathrm{~mm}$. This permitted the filter deposit to be centered in the holder more easily and also allowed for some expansion of the membrane filter before cementing in the holder. The filter deposit was held on a filtering funnel by applying suction. A thinned mixture of cement prepared by mixing equal parts of Barge all-purpose cement, ethyl acetate and cyclohexane was brushed on the platform of the holder. The filter was cemented to the holder platform by pressing the holder flat against the outer edge of the filter deposit and then allowed to dry. 
Neutron activation analysis (NAA) of the reground orchard leaves showed that the concentrations of iron, nickel, cobalt and chromium were much higher than in the certified SRM 1571. Therefore, it was important to determine if these introduced elements were homogeneously distributed throuthout the material. For this reason, sixteen samples of reground material (200 mg each) were taken and six elements, including iron and chromiurn, were analyzed by NAA. An analysis of variance of these concentrations in the material indicated that there were no gross inhomogeneities (not greater than five percent). These results indicated that the reground SRM 1571 was satisfactory for use provided that recertification of the introduced elements could be accomplished. An analysis of a number of these elements using NAA, atomic absorption spectrophotometry (AAS), and photon activation analysis (PAA) are included at the end of this report. Further work on the analysis of this material is still in progress.

The particle size distribution of the reground material is shown in figure 1. The area of about 80 percent of the 3000 particles examined was between zero and $7.5 \mathrm{~mm}^{2}$ (3.1 $\mu \mathrm{m}$ equivalent diameter). Less than 0.5 percent of the particles were within 82.5 and $105 \mathrm{\mu m}^{2}$, with no particles observed above $105 \mathrm{\mu m}^{2}$.

To determine if the cyclohexane treatment altered the trace element composition of the orchard leaves, NAA was performed on cyclohexane extracts and on the material after treating with cyclohexane. A number of elements, including $\mathrm{Br}, \mathrm{Mn}, \mathrm{Fe}, \mathrm{K}$ and $\mathrm{Na}$, were analyzed. The results showed that only sodium was affected by this treatment, and about 50 percent was extracted.

A simple technique was developed for measuring the uniformity of the deposits. This consisted of directing a laser beam about $2 \mathrm{~mm}$ in diameter normal to the sample, and measuring the intensity of the light transmitted [5]. Using a Beer's law calibration of absorbance vs areal density, the uniformity of the deposit was measured. Of the several samples examined having areal densities of 1.0 to $2.0 \mathrm{mg} / \mathrm{cm}^{2}$, variations in uniformity did not exceed $0.02 \mathrm{mg} / \mathrm{cm}^{2}$.

A number of coating materials were investigated and compared with regard to their ability to adhere to the sample and to provide protection from abrasion and humidity. These consisted of vapor-deposited Parylene films and heat-sealed overlays of polypropylene using Parafilm as a binder.

Also, orchard leaf deposits were prepared from suspensions in cyclohexane containing from 0.1 to 10 percent by weignt of polyisobutylene. Another important factor considered was the $x$-ray attenuation of these coatings, especially from elements of low atomic number such as phosphorus and sulfur. The attenuation of $\mathrm{P}, \mathrm{S}, \mathrm{K}$, and $\mathrm{CaK} \alpha$ lines was measured by comparing the background corrected peak intensities of coated and uncoated samples having the same areal densities using a wavelength-dispersive $\mathrm{x}$-ray spectrometer. 
The values obtained for various thicknesses of Parylene and of thin polypropylene and Parafilm coatings are summarized in tables 1 and 2, respectively. For Parylene coatings 75 to $193 \mathrm{~nm}$ thick, little change in attenuation was noted. Also, the $x$-ray background intensities from these samples were essentially the same as the uncoated samples except that the background of the $2500 \mathrm{~nm}$ thick sample was increased significantly. The attenuation values of the polypropylene-Parafilm coatings could not be reduced any further because thinner films were not available. In order to produce adherent deposits using polyisobutylene, as much as one percent or greater by weight of the polymer in cyclohexane was used. However, the amount of polyisobutylene retained on the samples varied considerably making it difficult to obtain reproducible attenuation data. For this reason, this coating material was considered unsatisfactory.

Table 1. Average Attenuation Values of Parylene Coatings a sample areal density $=2.0 \mathrm{mg} / \mathrm{cm}^{2}$

\begin{tabular}{|c|c|c|c|c|}
\hline \multirow{2}{*}{$\begin{array}{l}\text { No. of } \\
\text { Samples } \\
\end{array}$} & \multirow{2}{*}{$\begin{array}{c}\text { Parylene } \\
\text { Thickness, nm }\end{array}$} & \multicolumn{3}{|c|}{ Percent Attenuation } \\
\hline & & Element & Average & $\underline{S}^{b}$ \\
\hline 5 & 75 & $\mathrm{P}$ & 3 & 1.7 \\
\hline 3 & 75 & S & 2 & 1.3 \\
\hline 2 & 75 & $\mathrm{~K}$ & 1.4 & -- \\
\hline 5 & 117.5 & $P$ & 3.1 & 0.50 \\
\hline 5 & 117.5 & $\mathrm{~K}$ & 1.7 & 0.44 \\
\hline 5 & 158.0 & $\mathrm{P}$ & 5.4 & 0.90 \\
\hline 2 & 158.0 & $S$ & 5.2 & -- \\
\hline 4 & 158.0 & $\mathrm{~K}$ & 2.9 & 0.35 \\
\hline 7 & 166.5 & $\mathrm{P}$ & 5.0 & 0.81 \\
\hline 5 & 166.5 & $S$ & 4.3 & 0.92 \\
\hline 7 & 166.5 & $\mathrm{~K}$ & 2.6 & 0.69 \\
\hline 5 & 193.0 & $\mathrm{P}$ & 7.3 & 0.88 \\
\hline 3 & 193.0 & $\mathrm{~K}$ & 3.7 & 0.20 \\
\hline 3 & 2500 & $\mathrm{P}$ & 33 & 1.5 \\
\hline 3 & 2500 & $S$ & 28.9 & 0.71 \\
\hline 2 & 2500 & $\mathrm{~K}$ & 11.4 & -- \\
\hline
\end{tabular}

$a_{C a l c u l a t e d}$ from the expression $I_{u}-I_{c} / I_{u} \times 100$; where $I_{u}=$ peak intensity of uncoated sample, and $I_{c}=$ peak intensity of coated sample.

$\mathrm{b}_{\mathrm{S}}=$ standard àeviation of a single measurement. 
Table 2. Attenuation Values of Polypropylene and Parafilm coatings

\begin{tabular}{|c|c|c|c|c|c|c|}
\hline Sample \# & $\begin{array}{l}\text { Total coating } \\
\text { Thickness, } \mathrm{mg} / \mathrm{cm}^{2}\end{array}$ & $\mathrm{P}$ & $\begin{array}{l}\text { Perce } \\
\mathrm{S} \\
\end{array}$ & $\begin{array}{l}\mathrm{A} \text { Att } \\
\mathrm{Cl}\end{array}$ & $\begin{array}{l}\text { uation } \\
\mathrm{K} \\
\end{array}$ & $\mathrm{Ca}$ \\
\hline 1 & 1.2 & 28.1 & 23.2 & 14.1 & 10.9 & 8.5 \\
\hline 2 & 1.1 & 24.4 & 23.6 & 16.2 & 11.4 & 7.9 \\
\hline 3 & 1.2 & 26.3 & 24.4 & 13.6 & 10.1 & 8.3 \\
\hline Average & & 26.3 & 23.7 & 14.6 & 10.8 & 8.2 \\
\hline
\end{tabular}

The ruggedness of samples coated with Parylene films (75 to $200 \mathrm{~nm}$ thick) were tested by an air jet which impinged on the sample surface. Effects of humidity were observed when the samples were placed in a chamber maintained at 100 percent relative humidity.

The trace element composition of the starting material (di-para-xylylene dimer) was analyzed at Union Carbide Corporation. Of the 27 elements analyzed, sodium, magnesium, iron and aluminum were present in concentrations from 2 to 9 ppm. Silicon was $31 \mathrm{ppm}$, and the remaining elements were either below 1 ppm or were not detected. These results indicate that the Parylene material should be of sufficient purity for application in this work. Since the Parylene films appeared to furnish good sample protection, including high resistance to humidity, high purity, good adherence, and acceptable x-ray attenuation for the low atomic number elements, 60 samples were prepared and delivered to EPA containg from 0.1 to $5.0 \mathrm{mg} / \mathrm{cm}^{2}$ of orchard leaves coated with $117.5 \mathrm{~nm}$ of Parylene.

A photograph of a typical reference sample mounted in a holder is shown in figure 2 . 
Table 3. Preliminary Results of the Analysis of Reground SRM 1571 Orchard Leaves

\begin{tabular}{|c|c|c|c|c|}
\hline Elemert & $\begin{array}{l}\text { 10. of } \\
\text { Heas. }\end{array}$ & Average, $\mu \mathrm{g} / \mathrm{g}$ & Rel. Std. Dev. \% & $\begin{array}{l}\text { Certified Values } \\
\text { of SRM 1571, } \mu \mathrm{g} / \mathrm{g}\end{array}$ \\
\hline$F e^{a}$ & 3 & 791 & 0.2 & $300 \pm 20$ \\
\hline$i_{i}{ }^{a}$ & 3 & 22.5 & 0.5 & $1.3 \pm 0.2$ \\
\hline $\operatorname{Iii^{b}}$ & 1 & 21.5 & --- & \\
\hline $\mathrm{Cr}^{\mathrm{c}}$ & 15 & 41.97 & 3.70 & $(2.3)$ \\
\hline $\operatorname{Min}^{c}$ & 16 & 102.1 & 1.84 & $91 \pm 4$ \\
\hline$K^{c}$ & 16 & 1.49 (wt. \%) & 1.53 & $1.47 \pm 0.03$ (wt. \%) \\
\hline $\mathrm{Br}{ }^{\mathrm{C}}$ & 15 & 10.48 & 2.58 & (10) \\
\hline $\mathrm{Zn}^{\mathrm{C}}$ & 15 & 24.99 & 3.22 & $25 \pm 3$ \\
\hline
\end{tabular}

$$
\begin{aligned}
a & =\text { AAS } \\
b & =\text { PAA } \\
c & =\text { INAA }
\end{aligned}
$$

Values in parenthesis are not certified. 


\section{CONICLUSIONS}

Refertuce samples consisting of uniform layers of reground orchard leaves of krowr composition, i.e., INBS SRM 1571, on membrane filters were prepared for the standardization of $x$-ray fluorescence spectrometers. These samples have areal densities of 0.1 to $5.0 \mathrm{mg} / \mathrm{cm}^{2}$, and are coated with a thin polymer film for protection against abrasion and moisture. 


\section{REFERENCES}

1. J. A. Cooper, inucl. Instr. and Meth. 106, 525 (1973).

2. R. D. Giauque, F. S. Goulding, J. M. Jaklevic and R. H. Pehl, Anal. Chem. 45,671 (1973).

3. F. W. Reuter, III, Anal. Chem. 47, 1763 (1975).

4. F. S. Goulding and J. M. Jaklevic, EPA Report No. EPA-R2-73-182, April 1973.

5. E. C. Kuehner and W. A. Cassatt, A Laser Microphotometer for Determining Uniformity of Particulate Deposits on Membrane Filters, in press.

Identification of any commercial product does not imply recommendation or endorsement by the National Bureau of Standards, not does it imply that the material or equipment identified is necessarily the best available for the purpose. 


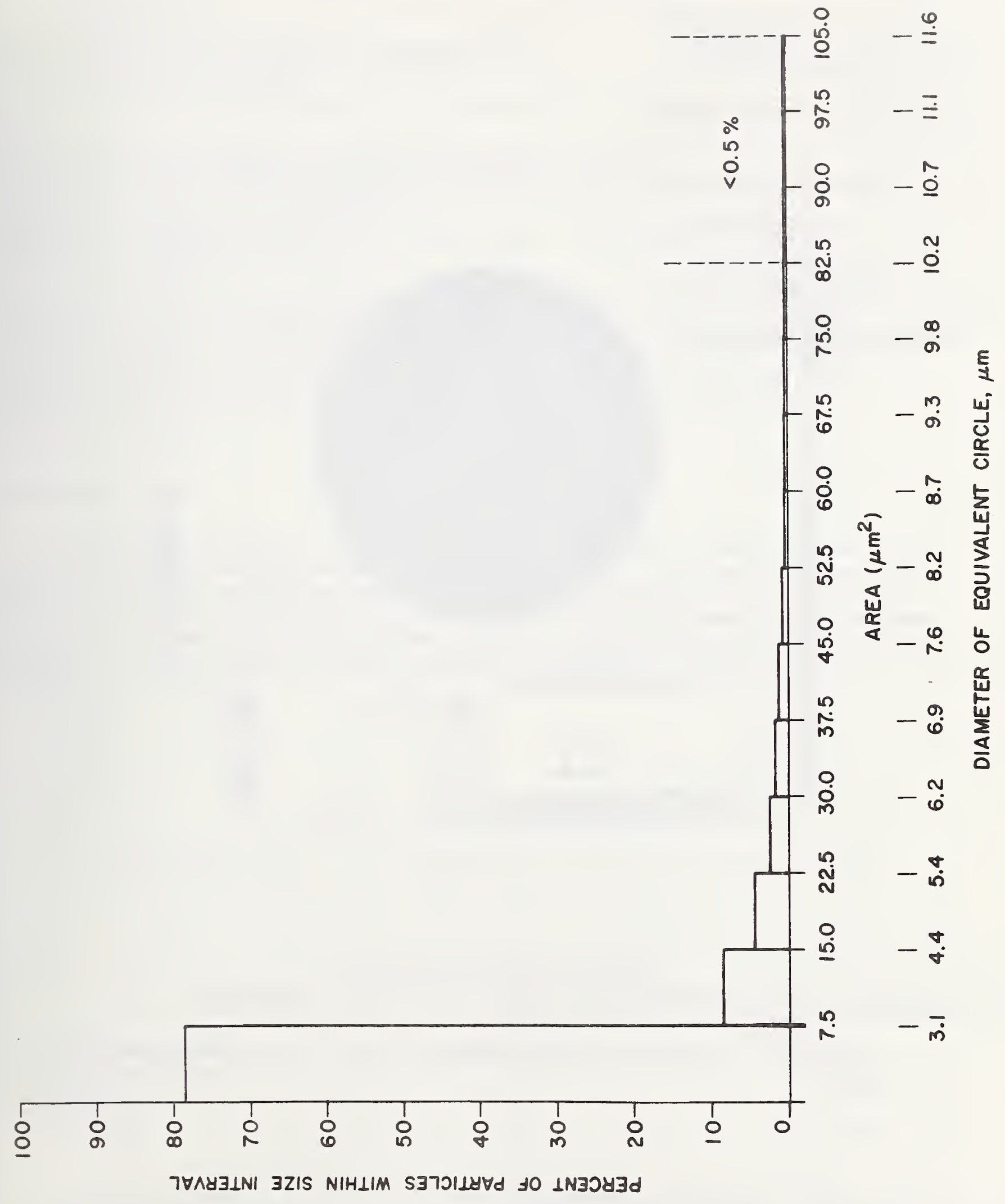

Pimure 1. Particle size distribution of orchard leaves. 

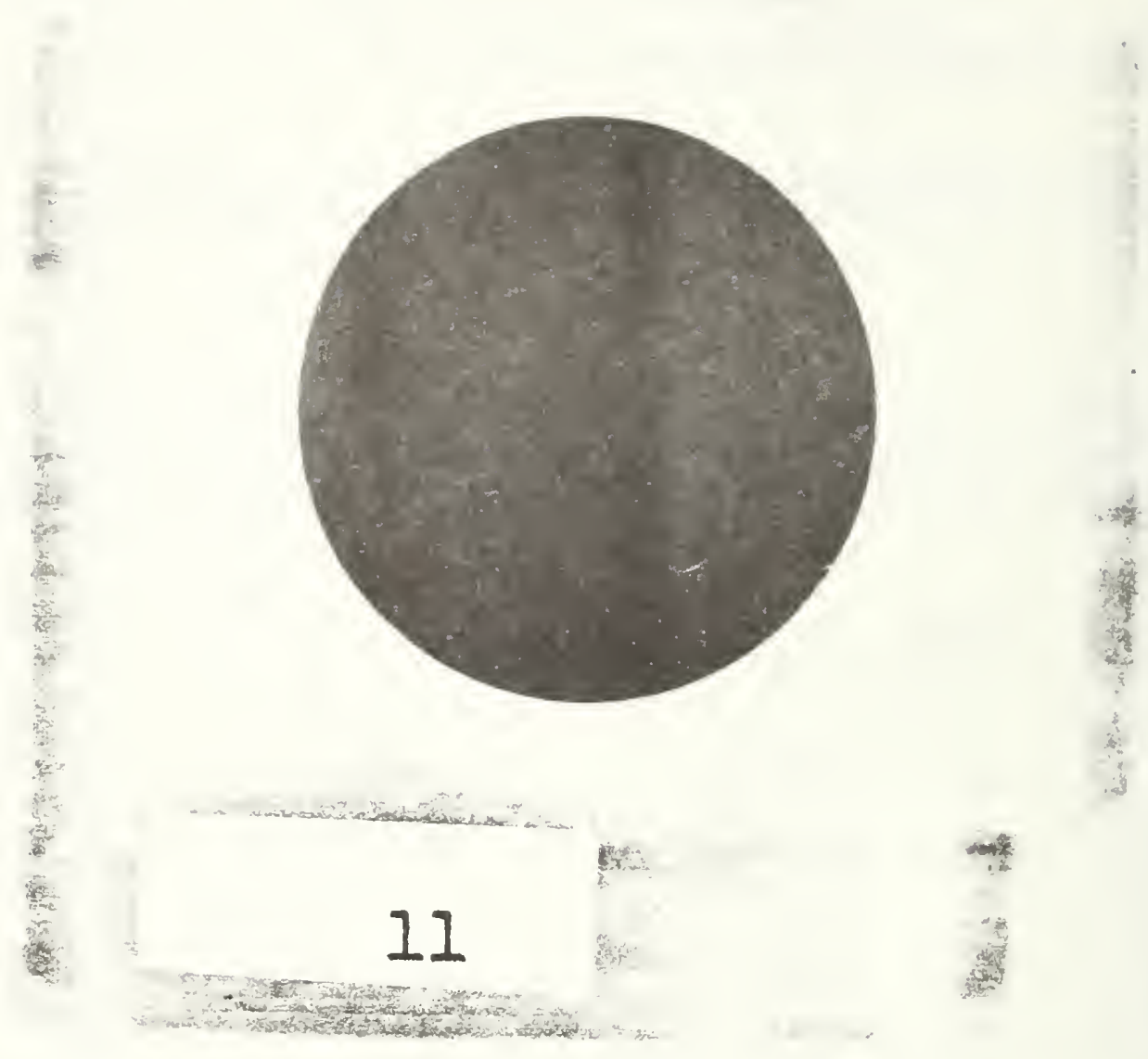

का

Figure 2. Reference sample mounted in holder (actual size $5 \times 5 \mathrm{~cm}$ ). 


\begin{tabular}{|c|c|}
\hline $\begin{array}{l}\text { 1. REFCRT } \\
\qquad \text { EPA- } 600 / 2-76-126\end{array}$ & 3. FECIPIENT'S ACCESSIONNO. \\
\hline $\begin{array}{l}\text { ATIEAVOSUSTITLE } \\
\text { DEVEIOPMENT OF THIN CALIBRATION STANDARDS FOR } \\
\text { X-RAY FLUORESCENCE ANALYSIS }\end{array}$ & $\begin{array}{l}\text { 5. REPORT DATE } \\
\text { MaY } 1976 \\
\text { 6. PERFOAMING ORGANIZATION CODE }\end{array}$ \\
\hline $\begin{array}{l}\text { 7. ALTHOÂl( } \\
\text { P. A. Pella, E. C. Kuehner, and W. A. Cassatt }\end{array}$ & 8. PERFORMING ORGANIZATION REPOAT NO. \\
\hline $\begin{array}{l}\text { 9. PERFOANING OAC M!zATION NAME AND ADDRESS } \\
\text { Analytical Chemistry Division } \\
\text { National Bureau of Standards } \\
\text { Washington, DC } 20234\end{array}$ & $\begin{array}{l}\text { 1A1010 } \\
\begin{array}{ll}\text { 11. CONTRACT/GRANT NO. } \\
\text { EPA-IAG-100 } & \text { (D) } \\
\text { DPA-IAG-D4-F849 }\end{array}\end{array}$ \\
\hline $\begin{array}{l}\text { 12. SPONSORING AGENCY WAME AND ADDRESS } \\
\text { Environmental Science Research Iaboratory } \\
\text { Office of Research and Development } \\
\text { U. S. Environmental Protection Agency } \\
\text { Research Triangle Park, NC } 27711\end{array}$ & $\begin{array}{l}\text { 13. TYPE OF REPORT AND PERIOD COVERED } \\
\text { Final } 6 / 1 / 7 / 74-6 / 1 / 75 \\
\text { 14. SPONSORING AGENCY CODE } \\
\text { EPA-ORD }\end{array}$ \\
\hline
\end{tabular}

15. SUPPLENENTARY NOTES

16. ABSTRACT

Particulate reference samples have been prepared for the standardization of $\mathrm{X}$-ray fluorescence spectrometers used in the analysis of air particulate matter. Uniform layers of reground orchard leaves of known composition, i.e., National Bureau of Standards Standard Reference Material 1571, were deposited on membrane filters and coated with a thin polymer film for protection against abrasion and moisture. These samples have been prepared with mass per unit area of 0.1 to 5.0
$\mathrm{mg} / \mathrm{cm}^{2}$.

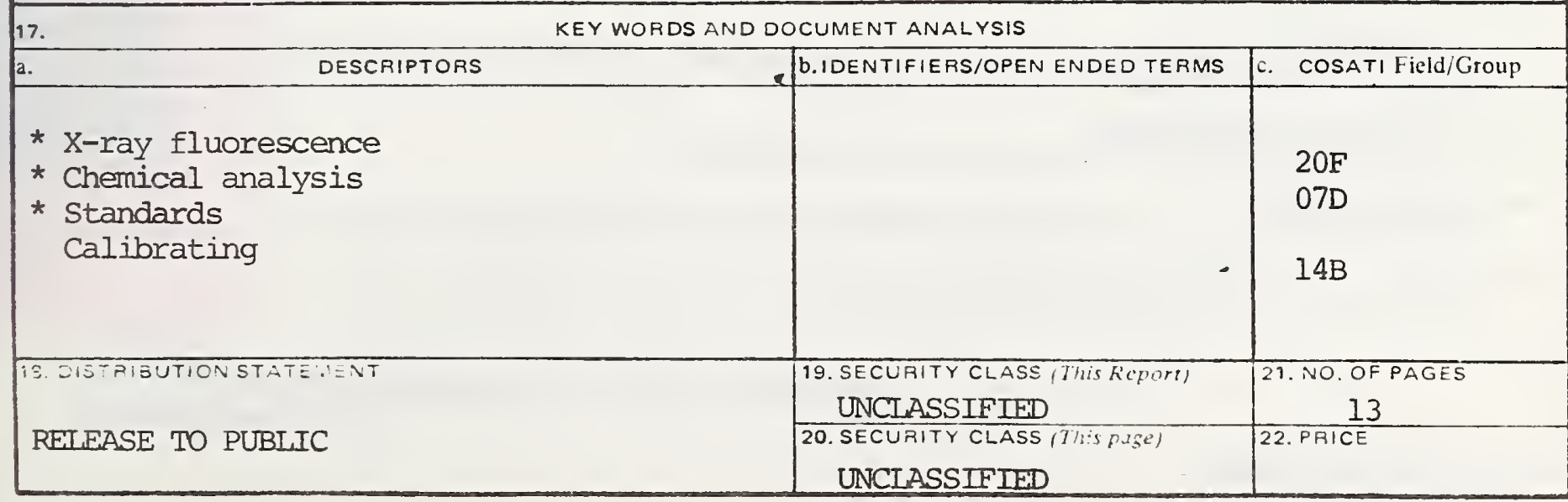




\section{INSTRUCTIONS}

1. REPORT NUPBBER

Insert tise EPA report number as it appeass on the cover of the publication.

2. LEAVE BLANK

3. RECIPIENTS ACCESSIONINUMBER

Rescrved for use by e.rih report recipient.

4. TITLE AND SUBTITLE

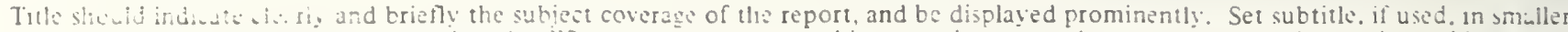

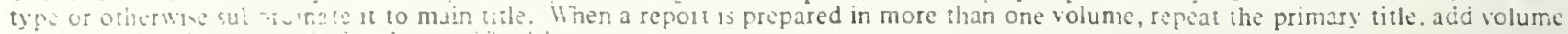

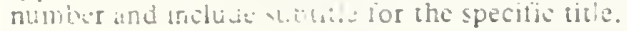

5. REPDRT DATE

fach ripert shill carry a dute indicatng at least month and year. Indicate the basis on which it was selected le.g., date of issue, date of approicl, ciate of pre ï arius, etc.).

6. PERFORMING ORGSNIZATION CODE

Leave b!ank.

7. AUTHC:B(S!

Give ndi..e(s) in comentional order (John R. Doe, J. Robert Doe, etc.). List author's affiliation if it differs from the performing organization.

8. PERFOPMING ORGAIIZATION REPOAT RUMBER

Inselt if pertorming.

9. PERFORMING ORGANIZATION NAME AND ADDRESS

Give name, street. cijy. state. and ZIP code. List no more than two levels of an organizational hirearchy.

10. PROGRAM ELEMENT NUNBBER

Use the program element :tumber under winch the report was prepared. Subordinate numbers may be included in parentheses.

11. CONTRACT/GRANT NUIMBER

Insert contract or grant nu.mber under which report was prepared.

12. SPONSORING AGE:ICY NAME AND ADDRESS

Include ZIP code.

13. TYPE OF REPORT AND PERIOD COVERED

Indicate interim tinal, etc., and if applicable, dates covered.

14. SPONSORING AGENCY CODE

Leave blank.

15. SUPPLER.JENTAFY NOTES

Enter information not incluiled elsewhere but useful, such as: Prepared in cooperation with, Translation of, Presented at conference of, To be published in, Supersedes, Supplements, etc.

16. ABSTRACT

Include a brief (200 words or less) factuai summary of the most significant information contained in the report. If the report contains a significant bibliography or literature surey, mention it here.

17. KEY WORDS AND DOCURENT ANALYSIS

(a) DLSCRIPTORS - Select from the Thesaurus of Engineering and Scientific Terms the proper authorized terms that identify the major concept of the research and are sufnciently specitic and precise to be used as index entries for cataloging.

(b) IDENTIFIERS AND OPEV-ENDED ILR:US - Use identifiers for project names, code names, equipment designators, etc. Use openended terms written in descriptor form for those subjects for which no descriptor exists.

(c) COSATI FIELD GROLP - Field and group assignments are to be taken from the 1965 COSATI Subject Category List. Since the majority of documents are multidisciplinary in nature. the Primary Field/Group assignment(s)"will be speciric discipline. area of liuman endeavor, or ty pe of ptysical object. The application(s) will be cross-referenced with secondary Field, Group assignmenis that will tollow the primury posting(s)

18. DISTRIBUTION STATEMENT

Denote relcasabints to the public or linitation for reasons other than security for example "Release Unlimited." Cite any arailability to the public, whth address and price.

19. \& 20. SEEURITY CLASSIFICATION

DO NOT submit classificd reports to the National Fechnical Information service.

21. NUMBER OF PAGES

Incert the total nuatz:r of peges. includins this one and unnumbered pages, but exclude distribution list, if any.

22. PRICE

Insert the price set by the National Technical Information Service or the Government Printing Office. if known. 